\title{
Feasibility Study of Ornamental Plant Business In Covid Pandemic at Baturaja OKU South Sumatera
}

\author{
Munajat \\ Universitas Baturaja \\ Email: munajat.ub@gmail.com \\ Fifian Permata Sari \\ Universitas Baturaja \\ Email: fifianpermatasari@gmail.com
}

\begin{abstract}
The ornamental plant business is a very promising and profitable one, especially after the early 2019 ornamental plant trend. Several varieties of ornamental plants can be sold at high rates, and customers are willing to pay high amounts for them to add to their collections. This occurrence can also be found in the city of Baturaja. Many businesses lost money during the Covid-19 pandemic, including the ornamental plant industry. The fall in people's purchasing power has an impact on the ornamental plant industry as well. As a result of their losses, many business owners are unable to live. The purpose of this research is to assess the viability of ornamental plants in the city of Baturaja, particularly during the Covid-19 pandemic. The census approach was used in this investigation, and the saturated random sample method was applied. The feasibility analysis utilizing the $\mathrm{R} / \mathrm{C}$ ratio is the analytical procedure utilized in the processing of research data. While the data was gathered from 15 ornamental plant business actors in Baturaja. The results demonstrated that the ornamental plant business in the city of Baturaja was indeed feasible throughout the Covid pandemic with an $\mathrm{R} / \mathrm{C}$ value of 1.65.
\end{abstract}

Keywords: Feasibility study, ornamental plant business, pandemic Covid

\begin{abstract}
Abstrak
Bisnis tanaman hias merupakan bisnis yang sangat menjanjikan dan menguntungkan, apalagi setelah terjadi trend tanaman hias di awal tahun 2019. Beberapa jenis tanaman hias dapat dijual dengan harga yang tinggi dan konsumen mau membeli dengan harga tinggi tersebut, untuk menambah koleksi. Fenomena ini juga terjadi di kota Baturaja. Selama pandemi Covid-19, banyak bisnis yang merugi, termasuk bisnis tanaman hias. Turun nya daya beli masyarakat juga berpengaruh terhadap bisnis tanaman hias. Membuat para pelaku usaha bisnis ini tidak mampu bertahan karena merugi. Penelitian ini bertujuan untuk menganalisis kelayakan usaha tanaman hias di kota Baturaja khususnya pada masa pandemi Covid-19. Metode yang digunakan dalam penelitian ini adalah metode sensus dan metode penarikan contoh yang digunakan adalah metode acak jenuh. Metode analisis yang digunakan dalam pengolahan data penelitian adalah analisis kelayakan menggunakan R/C ratio. Sedangkan data yang dikumpulkan berasal dari 15 pelaku usaha tanaman hias di kota Baturaja. Hasil penelitian menunjukkan bahwa usaha tanaman hias di kota Baturaja di masa pandemic Covid masih layak untuk terus diusahakan dengan nilai R/C sebesar 1.65 .
\end{abstract}

Kata kunci: Analisis kelayakan, bisnis tanaman hias, pandemic Covid

\section{Introduction}

Agricultural development in Indonesia does not only focus on agriculture in the plantation and food sectors, but also ornamental plants, which are classified as horticultural crops. Ornamental plants are currently starting to be ogled by the government and the private sector to be further developed because ornamental plants have a fairly profitable economic value. Ornamental plants are one of the horticulture commodities which has the biggest agribusiness prospects in Indonesia (Sandi et al., 2015). Based on the type, ornamental plants are divided into five parts, namely plant ornamental plants, leaf ornamental plants, ornamental fruit plants, root ornamental plants, and stem ornamental plants (Sholihin, 2019).

According to Mutakabbir (2019), ornamental plants are one of the horticultural plants that have a high enough economic value, so that the prospects are very bright for becoming a business or having 
promising business opportunities, both in terms of demand and the selling price are also very high. The development of ornamental plant business activities in the country is related to the increase in consumer income, demand for environmental beauty, the development of the tourism industry, as well as the construction of housing, hotels, and office complexes. The next ornamental plant business, according to Aritonang (2015), has benefits as a source of income for ornamental plant farmers and ornamental plant traders, as well as expanding employment opportunities. According to Sandi et al. (2015), the ornamental plant business is promising and has good agribusiness prospects. The demand for ornamental plants rises year after year, but this is not accompanied by supply. This is due to the fact that there are still few commercial players in the ornamental plant cultivation industry. Many ornamental plant players are also limited in their knowledge of ornamental plant cultivation and propagation. This business, on the other hand, is very promising due to the increasing demand for ornamental plants.

The ornamental plant business is currently a promising one because many individuals enjoy collecting ornamental plants for their yards. The hobby of collecting ornamental plants is currently popular among women, therefore if a new species of ornamental plant becomes available, it will be eagerly sought after for purchase and collection. This provides opportunities for ornamental plant entrepreneurs, including in the city of Baturaja. The profits from the ornamental plant business are quite promising and can provide quite a large profit. This is what makes the number of business people or ornamental plant entrepreneurs in the city of Baturaja increase. At the beginning of 2020, there were 15 ornamental plant entrepreneurs, out of 10 ornamental plant entrepreneurs in 2019, meaning that there was an addition of 5 ornamental plant entrepreneurs, the number of ornamental plant players. Data on ornamental plant business actors in Baturaja City in 2020 can be seen in Table 2 below.

Table 2. Ornamental plant Entrepreneurs in Baturaja City, 2020

\begin{tabular}{|c|c|c|c|}
\hline No & Name & Variety & Production \\
\hline 1 & Twins & $\begin{array}{l}\text { 1.Aglaonema } \\
\text { 2.Mawar } \\
\text { 3.Bonsai } \\
\text { 4.Sambang Dara } \\
\text { 5.Asoka }\end{array}$ & $\begin{array}{l}200 \\
150 \\
100 \\
150 \\
100\end{array}$ \\
\hline 2 & Kharisma Alam & $\begin{array}{l}\text { 1.Aglaoenema } \\
\text { 2.Mawar } \\
\text { 3.Bonsai } \\
\text { 4.Sambang Dara } \\
\text { 5.Asoka }\end{array}$ & $\begin{array}{l}250 \\
100 \\
150 \\
100 \\
100 \\
\end{array}$ \\
\hline 3 & Bibique & $\begin{array}{l}\text { 1.Aglaoenema } \\
\text { 2.Mawar } \\
\text { 3.Bonsai } \\
\text { 4.Sambang Dara } \\
\text { 5.Asoka } \\
\end{array}$ & $\begin{array}{c}100 \\
100 \\
50 \\
150 \\
100 \\
\end{array}$ \\
\hline 4 & Galery of Florist & $\begin{array}{l}\text { 1.Aglaoenema } \\
\text { 2.Mawar } \\
\text { 3.Bonsai } \\
\text { 4.Sambang Dara } \\
\text { 5.Asoka }\end{array}$ & $\begin{array}{l}250 \\
100 \\
150 \\
200 \\
150\end{array}$ \\
\hline 5 & Asmalia Florist & $\begin{array}{l}\text { 1.Aglaoenema } \\
\text { 2.Mawar } \\
\text { 3.Bonsai }\end{array}$ & $\begin{array}{l}200 \\
100 \\
125\end{array}$ \\
\hline
\end{tabular}




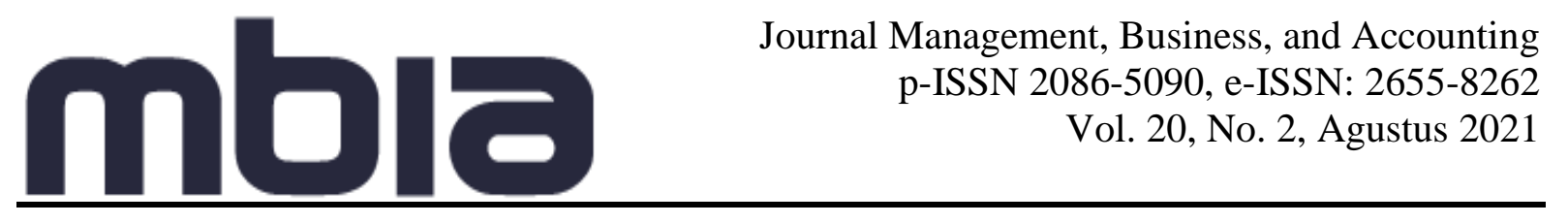

\begin{tabular}{|c|c|c|c|}
\hline & & $\begin{array}{l}\text { 4.Sambang Dara } \\
\text { 5.Asoka }\end{array}$ & $\begin{array}{l}100 \\
100\end{array}$ \\
\hline 6 & Lilys Home & $\begin{array}{l}\text { 1.Agalaoenema } \\
\text { 2.Mawar } \\
\text { 3.Bonsai } \\
\text { 4.Sambang Dara } \\
\text { 5.Asoka }\end{array}$ & $\begin{array}{l}150 \\
100 \\
100 \\
150 \\
100\end{array}$ \\
\hline 7 & Sukajadi plants & $\begin{array}{l}\text { 1.Agalaoenema } \\
\text { 2.Mawar } \\
\text { 3.Bonsai } \\
\text { 4.Sambang Dara } \\
\text { 5.Asoka }\end{array}$ & $\begin{array}{l}150 \\
100 \\
100 \\
100 \\
100\end{array}$ \\
\hline 8 & Cananga Odurata & $\begin{array}{l}\text { 1.Agalaoenema } \\
\text { 2.Mawar } \\
\text { 3.Bonsai } \\
\text {.4.Sambang Dara } \\
\text { 5.Asoka }\end{array}$ & $\begin{array}{l}250 \\
100 \\
150 \\
100 \\
150\end{array}$ \\
\hline 9 & Roses & $\begin{array}{l}\text { 1.Agalaoenema } \\
\text { 2.Mawar } \\
\text { 3.Bonsai } \\
\text { 4.Sambang Dara } \\
\text { 5.Asoka }\end{array}$ & $\begin{array}{l}300 \\
150 \\
100 \\
150 \\
100\end{array}$ \\
\hline 10 & Mbah Florist & $\begin{array}{l}\text { 1.Agalaoenema } \\
\text { 2.Mawar } \\
\text { 3.Bonsai } \\
\text { 4.Sambang Dara } \\
\text { 5.Asoka }\end{array}$ & $\begin{array}{l}150 \\
100 \\
150 \\
100 \\
100\end{array}$ \\
\hline 11 & Asmalia Florist & $\begin{array}{l}\text { 1.Agalaoenema } \\
\text { 2.Mawar } \\
\text { 3.Bonsai } \\
\text { 4.Sambang Dara } \\
\text { 5.Asoka }\end{array}$ & $\begin{array}{l}250 \\
150 \\
100 \\
150 \\
100\end{array}$ \\
\hline 12 & Misdiati Florist & $\begin{array}{l}\text { 1.Agalaoenema } \\
\text { 2.Mawar } \\
\text { 3.Bonsai } \\
\text { 4.Sambang Dara } \\
\text { 5.Asoka }\end{array}$ & $\begin{array}{c}250 \\
150 \\
100 \\
100100\end{array}$ \\
\hline 13 & Heni Etrika Florist & $\begin{array}{l}\text { 1.Agalaoenema } \\
\text { 2.Mawar } \\
\text { 3.Bonsai } \\
\text { 4.Sambang Dara } \\
\text { 5.Asoka }\end{array}$ & $\begin{array}{l}250 \\
150 \\
100 \\
100 \\
150 \\
\end{array}$ \\
\hline 14 & Rengga Florist & $\begin{array}{l}\text { 1.Agalaoenema } \\
\text { 2.Mawar } \\
\text { 3.Bonsai } \\
\text { 4.Sambang Dara } \\
\text { 5.Melati }\end{array}$ & $\begin{array}{l}250 \\
100 \\
150 \\
150 \\
100 \\
\end{array}$ \\
\hline 15 & Avril's Florist & $\begin{array}{l}\text { 1.Agalaoenema } \\
\text { 2.Mawar } \\
\text { 3.Bonsai } \\
\text { 4.Sambang Dara }\end{array}$ & $\begin{array}{l}250 \\
100 \\
100 \\
150\end{array}$ \\
\hline
\end{tabular}


Source :Departement of Agriculture, Food Crops and Horticulture OKU, 2019.

150

The addition of the number of ornamental plant entrepreneurs from 2019 to 2020 shows that the ornamental plant business is very promising. However, during the Covid-19 pandemic, people's purchasing power for ornamental plants decreased. This is what makes it worthwhile to investigate the viability of the ornamental plant business during the Covid pandemic in Baturaja City, OKU Regency, South Sumatra.The purpose of this research is to assess the viability of the ornamental plant business during the Covid epidemic in Baturaja City, OKU, South Sumatra.

\section{Literature Review}

Sholihin et al., 2016 in his research on the financial analysis of the Raphis Excelsa ornamental plant business, aimed to analyze the financial feasibility and sensitivity of the Raphis Excelsa ornamental plant in the Labuai farmer group, Bukit Raya District, Pekanbaru City, to changes in input prices and output prices with the results of this study. R/C 1.57

Mutakabbir et al., 2019 in their research on the analysis of the financial feasibility of ornamental plant businesses in the city of Samarinda, aims to analyze the income of the ornamental plant business carried out in the city of Samarinda and the financial feasibility of the ornamental plant business in the city of Samarinda with the results of the R/C 1.82 research.

Bestari (2017) in their research on the analysis of the financial feasibility of chrysanthemum farming in the green leaf nursery, Bandungan district, Semarang. Hamidah et al., 2017 in their research on the analysis of the financial and economic feasibility of banyan dollar farming (a case study in Tulungwanar village, Shoot sub-district, Lamongan district), aims to examine the activities and financial and economic feasibility of the dollar banyan ornamental plant business. Analyzing the amount of income earned on the dollar from banyan ornamental plant cultivation. To analyze the amount of production and costs in the dollar for banana ornamental plant farming.

Siregar, 2013 in his research on the analysis of orchid and anthurium ornamental plant farming, aims to determine the management system of the Orchid and Anthurium farming business in the research area, to determine the amount of production costs of Orchids and Anthuriums in the research area, and to determine the level of financial feasibility of farming Orchids and Anthuriums in the research area with $\mathrm{R} / \mathrm{C} 2.04$ research results.

Sandi et al. (2015) demonstrated that ornamental plants are still horticultural products with significant agribusiness prospects, including in Sukabumi, in their research on the feasibility analysis of Chrysanthemum ornamental plant cultivation in Sukabumi. The demand for ornamental plants increases by $3 \%$ every year, but this is not accompanied by supply because there are still few players in the cultivation of these ornamental plants. According to the findings of this study's analysis, the ornamental plant business can return its capital in 4 years and 1 month with an $\mathrm{R} / \mathrm{C}$ of 1.5.

Sitanjak, W., 2021 discovered that all types of ornamental plants have an R/C above 1.3 with a direct marketing model, where consumers come directly to buy ornamental plants and can order to the seller and then delivered directly to the consumer, in his research on the feasibility analysis of ornamental plants and their marketing model in Panribuan District, Simalungun Regency.

\section{Concept of Business Feasibility}

The concept of business feasibility using the $\mathrm{R} / \mathrm{C}$ ratio is a business feasibility that is analyzed using a variety of ratios to determine relative profits divided by total costs incurred. 
If the $\mathrm{R} / \mathrm{C}$ value obtained is greater than one, the business is said to be feasible. This is possible because a higher $\mathrm{R} / \mathrm{C}$ value means a higher level of profit earned in a business.

The public, particularly those involved in business, has recently become more aware of feasibility studies. The numerous opportunities and opportunities that exist in the business world have necessitated an assessment of the extent to which these opportunities can provide benefits when implemented. A business feasibility study is the process of determining the extent of the benefits obtained from carrying out a business activity (Ibrahim, 2014). A feasibility study is a comprehensive and in-depth examination of the viability of a business. The results of comparing all economic factors that will be allocated to a new business or business with the returns that will be obtained within a certain period of time are referred to as the feasibility of running a business. The goal of conducting a business feasibility study is to avoid delays in large-scale investments that turn out to be unprofitable. Because investment businesses generally require large sums of money and have a long-term impact on the company. The expected financial profit is used to determine the viability of a business activity. A business activity is said to be feasible if it generates a profit. A business activity, on the other hand, is said to be unfeasible if it does not provide financial benefits (Kasmir and Jakfar, 2014). According to Kasmir and Jakfar (2014), the purpose of a feasibility study is to ensure that the business or project being carried out is not in vain, or that money, energy, time, and thoughts are not wasted and that unnecessary problems do not arise in the future. Even the existence of a business or project will provide a variety of advantages and advantages to various parties.

Business feasibility can assess the viability of an idea generated by a single entrepreneur. The feasibility of a business can be determined by using two general criteria: $\mathrm{R} / \mathrm{C}$ and $\mathrm{BEP}$. $\mathrm{R} / \mathrm{C}$ is an abbreviation for return cost ratio, also known as the ratio or ratio between revenues and costs. It can be expressed mathematically as follows:

$$
\mathrm{A}=\mathrm{R} / \mathrm{C}, \mathrm{R}=\mathrm{C}(\mathrm{Py} . \mathrm{Y}), \mathrm{YC}=\mathrm{FC}+\mathrm{VC}, \mathrm{A}=\{(\mathrm{Py} . \mathrm{Y}) /(\mathrm{FC}+\mathrm{VC})\}
$$

Where $\mathrm{R}$ denotes revenue, $\mathrm{C}$ for costs. FC is Fixed Costs, Price of Output are denoted by Py and VC is for Variable Costs. It is according to Soekartawi (2017). The break even point is defined as the point at which total revenue equals total cost. The occurrence of a return to principal $=\mathrm{TC}$ depends on the long flow of receipts from a farm that can cover all operating and maintenance costs as well as other capital costs based on the period of implementation of a farm (Sunarjono, 2012).

The Revenue Cost Ratio, as defined by Soekartawi (2015), is a comparison of total revenue and total production costs. The formula is as follows:

$$
\mathrm{R} / \mathrm{C} \text { Ratio }=\mathrm{TR} / \mathrm{TC}
$$

Description :

$$
\begin{aligned}
& \mathrm{TR}=\text { Total Revenue } \\
& \mathrm{TC}=\text { Total Cost }
\end{aligned}
$$

If $\mathrm{R} / \mathrm{C}>1$, then a business is said to be feasible because it is profitable. If $\mathrm{R} / \mathrm{C}=1$, then the business is said to break even or does not provide a profit, in the business feasibility analysis, 
this condition is declared unfeasible. If $\mathrm{R} / \mathrm{C}<1$, then the business is declared unfeasible because it cannot provide a profit.

\section{Research Method}

The research method used is the census research method and the sampling method used is the saturated sampling method, with 15 ornamental plant entrepreneurs taken as the samples in this research. The data used in this research is primary and secondary data, with feasibility study for the analysis. This research used the $\mathrm{R} / \mathrm{C}$ ratio as the analysis technique.

\section{Result and Discussion}

The results showed that the ornamental plant business during the Covid pandemic in Baturaja City, OKU, South Sumatra, was still feasible to run. This is shown from the results of the R/C ratio analysis, which shows a number greater than 1 , namely with an $\mathrm{R} / \mathrm{C}$ of 1.05 . This eligibility figure is actually very small or almost touching the number 1 , which means break even, because during the pandemic, people's purchasing power was very low.

Feasibility of the ornamental plant business was measured by feasibility analysis using the R/C ratio. $\mathrm{R} / \mathrm{C}$ is a comparison between total revenue (revenue) and total cost (cost) of the ornamental plant business in Baturaja City. By calculating the $\mathrm{R} / \mathrm{C}$ ratio, it can be seen whether the ornamental plant business is economically feasible (profitable) or not economically feasible (unprofitable). There are three possibilities obtained from the comparison between revenue (R) and cost $(\mathrm{C})$, namely:

If $R / C>1$ : Then the business is feasible to run.

If $\mathrm{R} / \mathrm{C} 1$, then the business is not feasible to run.

If $\mathrm{R} / \mathrm{C}=1$, then the business is in a break-even condition.

Furthermore, business feasibility will be analyzed using revenue and cost ratio (R/C) analysis. The formula is as follows:

$\mathrm{R} / \mathrm{C}=\mathrm{Receipt} /$ Total Cost

$=$ Rp. 518,750,000/Rp. 492.247,656

$=1.05$

The results of the analysis show that $\mathrm{R} / \mathrm{C}>1$, which is 1.05 , which means that each cost incurred is 1 rupiah, and will result in an income of $\mathrm{Rp} .1 .05$

The results of the analysis are in line with similar research in Pekanbaru City, as stated by Sholihin et al., 2016 in his research on the financial analysis of the Raphis Excelsa ornamental plant business. This research analyzed the financial feasibility and sensitivity of the Raphis excelsa ornamental plant in the Labuai farmer group, Bukit Raya District, Pekanbaru City to changes in input prices and output prices. The results of this study were R/C 1.57.

The results of the study are also in line with the results of the study by Mutakabbir et al., 2019 in their research on the analysis of the financial feasibility of ornamental plant businesses in the city of Samarinda. This research aimed to analyze the income of the ornamental plant business carried out in the city of Samarinda and the financial feasibility of the ornamental plant business in the city of Samarinda with the results of the R/C 1.82 research.

From several analysis results of similar research, the results are not much different from the research conducted in Baturaja City. Based on the results of data processing using ratio analysis to analyze the feasibility of ornamental plant businesses during the Covid pandemic, the $\mathrm{R} / \mathrm{C}$ value was 1.05 . This 
shows that the ornamental plant business is still feasible to continue cultivating during the Covid pandemic.

\section{Conclusion}

The results of the analysis show $\mathrm{R} / \mathrm{C}>1$, which is 1.05 , this shows that the ornamental plant business during the Covid pandemic in Baturaja City OKU South Sumatra, is still profitable to cultivate.

\section{Reference}

Lawrence, S. et al. (2001). Persistence of Web References in Scientific Research. Computer, 34, 2631. http://dx.doi.org/10.1109/2.901164

Aritonang. (2015). Business Forecasting. Ghalia. Jakarta.

Bestari, S. A. (2017). Analisis Kelayakan Finansial Usahatani Bunga Krisan Di Daun Hijau Nursery Kecamatan Bandungan Kabupaten Semarang (Doctoral dissertation, PS S1 AGRIBISNIS).

Central Bureau of Statistics South Sumatra. (2019). South Sumatra in Figures 2019. South Sumatra Province.

OKU Food Crops and Horticulture Department. (2019). Annual Report. Baturaja OKU.

Hamidah E. (2017). Financial and Economic Feasibility Analysis of Farming. Banyan Dollars. Lamongan.

Henry, S. (2012). Cost Concepts and Management Accounting. Riau.

Ibrahim. (2014). Business Feasibility Study. Jakarta.

Kasmir and Jakfar. (2014). Business Feasibility Study. Jakarta.

Mutakabbir, et. al. (2019). Analysis of Financial Feasibility of Ornamental Plants Business in Samarinda City. JAKP (Journal of Agribusiness and Agricultural Communication).Vol. 2, No 1, Apr 2019. Pages: 25-34.

Sandi, et.al. (2015). Feasibility Analysis of Ornamental Plant Cultivation in Sukabumi. Integra Engineering Journal. National Institute of Technology, ITENAS. No.1 Vol.03 January 2015.

Santoso. (2019). The Definition of Ornamental Plants. Accessed November 21, 2020

Sholihin, R, Tarumun S, and Muwardi, D. (2019). Financial Analysis of Raphis Excelsa Ornamental Plant Farming (Case Study of Labuay Farmers Group, Husada Street, Raya Hill District, Pekan Baru City.

Siregar. (2013). The Analysis of Ornamental Plants Farming of Orchids and Anthuriums. Medan.

Sitanjak, W. (2021). Business Feasibility Analysis and Marketing Model of the 3 Dolok Orchid Plant Case Study of the Nagori 3 Dolok Orchid Business, Panribuan District, Simalungun Regency. Tower Journal, Vol XV No.02 April 2021.

Soekartawi. (2014). Analysis of Income and Feasibility of Ornamental Plant Farming in Randomayang Village, Bambalamotu District, North Mamuju Regency 2014 Palu. Agrotekbis 2 (6): 634 -638, December 2014.

Sulistiya and Anggraeni R. (2011). Financial and Economic Feasibility of Ornamental Plants Business in the Special Region of Yogyakarta. Agros Vol 8 No. September 3, 2011.

Sunarjono. (2012). Feasibility Analysis of Rose Ornamental Plants 2012. Accessed November 25, 2020.

Supriyanto. (2010). Research Methods Accessed on November 20, 2020.

\section{Copyright Disclaimer}

Copyright for this article is retained by the author(s), with first publication rights granted to the journal. 